\title{
STUDY OF PONDS IN KATHMANDU VALLEY AND ANALYSIS OF THEIR PRESENT SITUATION
}

\author{
Dr. Bikash Adhikari*, Anmol Parajuli* , Prakash Adhikari*
}

\begin{abstract}
Ponds in Kathmandu were constructed to feed the sub surface aquifers of stone spouts and dug wells at all seasons. The study focuses on how the ponds have been saved, reduced in size or completely lost. The causes behind the degradation of ponds are forces of intervention and disturbances that lead to the loss of the originality, quality and quantity of ponds throughout its timeline. Out of eight existing ponds in the study area, 10 samples were taken from eight different ponds for quality assessment. The historical significances and status, uses as of 2019 are tabulated based on field survey. The paper focuses on the study of pH, Total Solids, Electrical Conductivity, Ammonia, Nitrate, Phosphate, Ammonia, Dissolved Oxygen, Biological Oxygen Demand, Total Organic Matter, Chlorophyll, E. Coli, and dimensions of existing ponds. The physical, social stresses and lack of regular inspection of ponds have contributed to their degradation. However, the existing ponds require sustainable management. Proper safeguarding mechanism should be developed for the regular aeration of water in the ponds such as fountains so that the ponds have more dissolved oxygen eliminating faulty smell and control fish death.
\end{abstract}

Keywords: aquifers, water quality assessment, E. coli, degradation, aeration.

\section{Introduction}

Ponds are extraordinary artifacts that provide unique values and purposes. Ponds in Kathmandu Valley lie inside or outside settlements that are sources of surface water and are used for domestic purposes, irrigation, running water mills and even for dumping sewerage and garbage(Antony and G., 1985). Ponds in Kathmandu were basically constructed to feed the sub surface aquifers of stone spouts and dug wells at all seasons (Pant, 2009). The indigenous inhabitants in the valley preferred ponds within the settlement area to

\footnotetext{
* Department of Environmental Science and Engineering, Kathmandu University, Dhulikhel

* Nepal Engineering College, Pokhara University

* Correspondence: Dr. Bikash Adhikari, Anmol Parajuli
}

Email: bikashadhikari@ku.edu.np, anmolparajuli7@gmail.com 
beautify the landscape and also to create feasible space. In modern days, ponds essentially have social and economic purposes besides religious and cultural significances such as Fishery and recreational activities. There are approximately one hundred ancient lakes and ponds in the valley (Sharma, 1992; Sharma, 1989). But as their usage has receded, their importance has receded due to which, their maintenance and renovation couldn't take place and gradually have started to fall. However, few ponds are still maintained well.

Lainchour Pokhari, which was the biggest pond of Kathmandu, has now taken the form of a building. It is now a place for Nepal Scouts building. Among the few ancient remaining ponds are Guita Pokhari, Patan and Lagankhel Pokhari. Taudaha, Nagdaha, Siddha Pokhari, Pim Bahal Pokhari, Rani Pokhari, Nag Pokhari, Kamal Pokhari and Gahana Pokhari are some of the better known ones carrying cultural significances (Amatya, 2003). Taudaha, Nag Pokhari and Nagdaha, for example, are visited during the Nag Panchami festival. Taudaha is the only natural lake that serves as ecological habitat for a significant number of wetland birds (Shrestha, 2003). In the past, Bhaktapur had numerous ponds out of which there are still 33 of them. Siddha Pokhari, a focalpoint during Dashain measuring $275 \mathrm{~m}$ by $90 \mathrm{~m}$, is said to have been built in the 15th century. Barhe Pukhu is another big pond that lies in north-east of the city. Ancha Pukhu, to the north of the city, has a stone image of the reclining Lord Vishnu at its center, and it is a place where many religious events take place. The Lalitpur Sub-Metropolitan City Office (LSMC) states that there are 25 Pokharis in the city today with the major ones being Prayag, Jawalakhel and Pim Bahal. But according to Prayag Joshi, he listed 39 ponds in Patan, out of which 16: condition, 9: encroached reducing size and 14: completely lost. Pim Bahal Pokhari was built in the 14th century and is one of the more famous ponds in Patan. However, it had lain in a state of neglect for a long time. This ancient city has somehow had some trouble maintaining its historical ponds. According to a recent news report, however, three ponds - Nehoo, Saptapatal and Purnachandi - have been earmarked by the LSMC for extensive repair and renovation. This is mainly an attempt to recharge the ponds by harvesting rainwater in order to solve the city's acute drinking water problem.

The scenario of Kathmandu has changed from the last 50 years because it had to cope with large influx of people (Dixit and Upadhaya, 2005). As, the land of the city is regarded as an asset, there has had been insignificant protection initiatives. The profound knowledge of land use developed by Kirats, enriched during Lichhavi period and extended by the Mallas was overshadowed by the ignorance of state and later by the public mainly during Rana regime and Panchayat system (UN-HABITAT, 2008). Bal Mandir Pokhari in Naxal 
is transformed to Bal Mandir School. Similarly, Hattisar Pond in Hattisar was encroached. Pond in Bhairabstan Margh was destroyed during Rana regime. The public land which was kept with state to safeguard its proposed use were either grasped by the influential people in the government and disciple of the palace or brought in use other than ecological use. Ponds in Bishal Nagar, Ganesthan and Baluwatar were granted by his Majesty's to the homeless people as caretakers for their shelter but they encroached and transferred the ownership to their name and ponds were destroyed. Ikha Pokhari of Nyokha visibly exists but the majority of the area is replaced by Kanya Mandir School. Similarly, Police Head Quarter Office has been established above Sinduwaal Pokhari in Naxal. The knowledge and skill of recharging ground water to serve wells and stone spouts was well established in earlier time. Some of the ponds also served as waste water management especially grey water (Maharjan, 2012). The ponds which collects surface water and recharge the aquifers are lost because of ignorance, change in habits and economy and greed of people. The second negative intervention into the system is the construction of large buildings which requires deep foundation. With deep foundation there is a good chance these water channels can be destroyed knowingly or unknowingly. Shallow dug wells became popular in Kathmandu Valley in last two decades with the availability of concrete rings, cheap electric water pumps, and convenient plastic water tanks. The regular uncertainty of city supply attracted people towards the construction of dug wells. In the absence of regulating mechanisms to manage ground water, dug wells became popular. Unfortunately, this became one of the major reasons for the decrease in the discharge (UN-HABITAT, 2008).

\section{Materials and Methods}

The methodology involved extensive review of secondary data and consultation with key stakeholders that led to identification of research questions, selection of the study objectives and identification of appropriate sets of variables for inquiries. 
Table 1: Methodological tools

\begin{tabular}{|c|c|c|}
\hline Objectives & Indicators & Research tools \\
\hline $\begin{array}{l}\text { 1. Inventory of the ponds and } \\
\text { the reasons for the construction } \\
\text { of ponds }\end{array}$ & $\begin{array}{l}\text { - Number of ponds in } \\
\text { KMC } \\
\text { - Sector where water was } \\
\text { used and current usage }\end{array}$ & $\begin{array}{l}\text { - Key Informants' survey } \\
\text { - Literature review } \\
\text { - Field visit } \\
\text { - Secondary data }\end{array}$ \\
\hline $\begin{array}{l}2 \text { Stresses influencing in the } \\
\text { degradation/disappearance of } \\
\text { the ponds in KMC }\end{array}$ & $\begin{array}{l}\text { - Stresses and pressures } \\
\text { identification } \\
\text { - Impacts of those threats }\end{array}$ & $\begin{array}{l}\text { - Key Informants' survey } \\
\text { - Literature review } \\
\text { - Focus group discussion }\end{array}$ \\
\hline $\begin{array}{l}3 \text { Present day status of the } \\
\text { ponds which are in existence }\end{array}$ & $\begin{array}{l}\text { - Current state of ponds } \\
\text { - Identification of } \\
\text { potential threats } \\
\text { - Waterquality assessment }\end{array}$ & $\begin{array}{l}\text { - Literature review } \\
\text { - Key Informants' survey } \\
\text { - Field visit } \\
\text { - Focus group discussion }\end{array}$ \\
\hline $\begin{array}{l}\text { 4 Study of the physical chemical } \\
\text { and biological parameters of } \\
\text { water quality }\end{array}$ & - Water quality assessment & $\begin{array}{l}\text { - Water sample collection } \\
\text { - Laboratory test }\end{array}$ \\
\hline
\end{tabular}

\section{Study Area}

The study area lies within 32 wards of Kathmandu Metropolitan City. The city stands at an elevation of approximately 1,400 metres $(4,600 \mathrm{ft})$ in the bowl-shaped valley in Bagmati. The geographical location of the city is $27^{\circ} 38^{\prime} 32^{\prime \prime}$ to $27^{\circ} 45^{\prime} 7^{\prime \prime}$ North latitudes and $85^{\circ} 16^{\prime} 5^{\prime \prime}$ to $85^{\circ} 22$ '32'(Haack, 2009). East longitudes. According to the 2001 census, there are 671,846 inhabitants whereas increased to 975,453 inhabitants in 2011 (CBS, 2011; CBS, 2002; CBS, 2001). The Kathmandu valley with its three districts including Kathmandu District accounts for a population density of only 97 per square kilometer whereas Kathmandu metropolitan city has a density of 13,225 per square $\mathrm{km}$ and increased to 19,250 per square km (CBS, 2011; CBS, 2001).

\section{Climate and precipitation}

Kathmandu city has a warm temperate and humid climate. The average summer temperature varies from $24-28{ }^{\circ} \mathrm{C}$ with the maximum temperature as high as $37.2^{\circ} \mathrm{C}$ in the month of June and the average winter temperature is $10-13{ }^{\circ} \mathrm{C}$ and the minimum temperature was recorded as low as $-2.8^{\circ} \mathrm{C}$ in the month of January (DHM, 2015). The average annual rainfall is $1455 \mathrm{~mm}$ where $85 \%$ of rainfall occurs in May-September and the humidity is around $74 \%$ (DHM, 2015). 


\section{Land use}

KMC land use is mainly divided into five types: Urban/Built-up, Open space, Water body, Cultivated land and Natural vegetation for the simplicity of study (Pradhan, 2003).Dominant land use type in Kathmandu municipality is built-up which mostly comprises of residential and commercial, administrative and transportation areas. It occupies $65.60 \%$ of the total area whereas agricultural area contributes $16.80 \%$. Water resources consist of just $1.26 \%$ which consists of rivers and ponds. Ponds contribute just $0.12 \%$ of KMC (Pant, 2009).

\section{Status of ponds}

It is estimated that there are over 100 ponds inside the Kathmandu valley that includes Kathmandu, Patan, Bhaktapur, Sankhu and other villages (Pradhan, 2003). There are 16 traditional ponds in Kathmandu (Pradhan, 1990), 39 ponds in Patan (Joshi, 1992), 42 major ponds in Bhaktapur and 5 ponds in Sankhu. Sad but true, is the fact that the creation of ancestors are at high risk of falling and are deteriorating day by day. Like other heritages, ponds that are part of the culture are at major stress and on the way for its very deterioration unless proper actions are taken. The causes behind the degradation of ponds, in fact are stresses -forces of intervention and disturbance- that leads to the loss of the originality, quality and quantity of ponds throughout its timeline.

\section{Research methods}

\section{Sampling for quality assessment}

Out of eight existing ponds in the study area, 10 samples were taken from eight different ponds. Three samples were taken in four seasons, viz. pre-monsoon, monsoon, postmonsoon and winter. Two samples were taken from the larger ponds i.e. Kamal Pokhari and Nag Pokhari whereas one sample from each of the six smaller ponds in December, at 1 foot depth. Eight samples were taken 1 meter from the bank of the pond whereas two samples were taken from the center of the pond. The sampling sites were taken so that they represent the homogeneous water mass of the sampling sites. Following samples were taken from the eight sampling sites.

Site 1 (Nag Pokhari)

Site 2 (Hiti Pokhari)

Site 3 (Kamal Pokhari)

Site 4 (Raj Rajeshwori)

Site 5 (Rani Pokhari) 
Site 6 (Kamaladi Pokhari)

Site 7 (Ikha Pokhari)

Site 8 (Dayashwor Mahadev)

\section{Water quality assessment}

The water samples collected from eight different ponds were subjected to physical chemical and biological water quality examinations at water quality analysis laboratory of Environment and Public Health Organization (ENPHO).

Table 2: Water Quality Parameters

\begin{tabular}{|l|l|l|}
\hline Parameters & Unit & Test Methods \\
\hline Physical Parameters & & \\
\hline Temperature & ${ }^{0} \mathrm{C}$ & Thermometer \\
\hline $\mathrm{pH}\left(19^{\circ} \mathrm{C}\right)$ & - & $\mathrm{pH}$ meter \\
\hline Electrical Conductivity & $\mathrm{us} / \mathrm{cm}$ & Conductivity Meter \\
\hline Total solid & $\mathrm{mg} / \mathrm{L}$ & Gravimetric (filtration, weighing of residue) \\
\hline Chemical Prameters & & \\
\hline Chloride & $\mathrm{mg} / \mathrm{L}$ & Argentometric \\
\hline Ammonia & $\mathrm{mg} / \mathrm{L}$ & Spectrophotometric (Neslerization) \\
\hline Nitrate & $\mathrm{mg} / \mathrm{L}$ & UV Spectrophotometric (Screening) \\
\hline Total Phosphate & $\mathrm{mg} / \mathrm{L}$ & Ammonium molybdate ascorbic acid reduction \\
\hline Total Organic matter & $\mathrm{mg} / \mathrm{L}$ & Gravimetric \\
\hline Dissolved Oxygen & $\mathrm{mg} / \mathrm{L}$ & Atomic Absorption Spectrometer (AAS) \\
\hline $\begin{array}{l}\text { Biochemical Oxygen } \\
\text { Demand for 5 days at } \\
\text { 20 degree C }\end{array}$ & $\mathrm{mg} / \mathrm{L}$ & $\begin{array}{l}5 \text { days incubation at 20 degree C and tit } \\
\text { of initial and final dissolved oxygen }\end{array}$ \\
\hline Biological Parameters & & \\
\hline Chorophyll & $\mathrm{mg} / \mathrm{m} 3$ & Spectrophotometric \\
\hline E.coli & $\mathrm{CFU} / 100 \mathrm{ml}$ & Membrane Filtration \\
\hline
\end{tabular}

\section{Field survey}

The field survey involved key informants' survey and semi-structured interviews with different stakeholders. In order to put together an inventory of ponds and identify the causes and stresses behind the degradation of the ponds, interviews, sampling, Focused 
Group Discussion(FGD) were done. To identify the key informant, snow ball sampling was done in the initial phase of the field survey. Key informants interviews were conducted with the personnel from KMC who are involved in the decision making. The interview also includes personnel from ward offices, local leaders, social and NGO activists and elderly persons. Other important key informants were academicians, journalists, Ghuti Sansthan and department of archeology. Focus Group Discussions (FGD) were carried out at five different wards i.e ward nos. 1, 3, 8, 28 and 31 in the month of September, 2019. The location of the FGD included: Kamal pokhari club in Kamal pokhari, Dayashwor Mahadev temple in Lazimpath, Siddhi Shaligram Briddhashram (Home for the Elderly) in Pashuptinath temple, Kanya mandir in Nyokha, Ganesh Mandir in Kamaladi, Naxal youth club in Naxal and Rani Pokhari in Kantipath. At each location 10-15 people from the area representing different age groups, caste/ethnicity, gender and occupation participated in the FGD. The participants were asked to provide information relating to the history and origin of ponds, ponds which disappeared in different time frame. They were also asked to help us know about the change in demography and settlement pattern, land use and land cover changes, water use and the changes in the water supply situation and issues regarding to the degradation of ponds.

\section{Secondary data collection and Analysis}

The secondary data of the study were collected from published and unpublished sources from government and non-governmental organization and analysis and computation were done.

\section{Result and Discussions Inventory of ponds}

Based on the location, ponds can be divided in two categories-inner settlement ponds and external settlement ponds that are utilized for recharging the aquifers that are the sources of water for hitis and tun(Graney and Eriksen, 2004). Rani Pokhari, Lainchaur Pokhari, Ikha Pukhu, Kamal Pokhari are some external ponds whereas there are no inner settlement ponds remained in Kathmandu. The status of ponds and their uses are tabulated based on field survey. 
Table 3: Ponds and their uses

\begin{tabular}{|c|c|c|c|c|c|}
\hline S.No & Name of Pokhari & Status & Use & Place & Operation \\
\hline 1 & Rani Pokhari & Existing & $\begin{array}{l}\text { Cultural \& } \\
\text { fishery }\end{array}$ & Kantipath & Conserved \\
\hline 2 & Hiti Pokhari & Existing & Recreational & $\begin{array}{l}\text { Narayanhiti } \\
\text { Path }\end{array}$ & Conserved \\
\hline 3 & Kamal Pokhari & $\begin{array}{l}\text { Reduced } \\
\text { size }\end{array}$ & $\begin{array}{l}\text { Recreational \& } \\
\text { fishery }\end{array}$ & Gyaneshwor & Conserved \\
\hline 4 & Gahana Pokhari & Existing & Recreational & Tangal & Conserved \\
\hline 5 & Dayashwor mahadev & Existing & $\begin{array}{l}\text { Cultural \& } \\
\text { domestic use }\end{array}$ & Lainchour & Conserved \\
\hline 6 & Kamaladi & Existing & & Kamaladi & Abandoned \\
\hline 7 & Nag Pokhari & Existing & $\begin{array}{l}\text { Recreational and } \\
\text { cultural }\end{array}$ & Naxal & Conserved \\
\hline 8 & Sinduwaal Pokhari & Lost & Office & Naxal & $\begin{array}{l}\text { Police } \\
\text { Headquarter }\end{array}$ \\
\hline 9 & Ikha Pokhari & $\begin{array}{l}\text { Reduced } \\
\text { size }\end{array}$ & School & Nyokha & $\begin{array}{l}\text { Kanya Mandir } \\
\text { School }\end{array}$ \\
\hline 10 & Bachha Pokhari & Lost & Private & Naxal & Residential \\
\hline 11 & Kaitahiti mani Pokhari & Lost & Public & Kalimati & Market \\
\hline 12 & $\begin{array}{l}\text { Nag } \\
\text { Pokhari(Sundhara) }\end{array}$ & Lost & Private & Sundhara & Buildings \\
\hline 13 & Matule Pokhari & Lost & Private & Teku & Ambe building \\
\hline 14 & Lainchour Pokhari & Lost & Private & & Buildings \\
\hline 15 & Bal Mandir Pokhari & Lost & Public & Naxal & $\begin{array}{l}\text { Bal Mandir } \\
\text { School }\end{array}$ \\
\hline 16 & Hattisar Pokhari & Lost & Private & Hattisar & Encroached \\
\hline 17 & $\begin{array}{l}\text { Nag Pokhari } \\
\text { (Bhagwanstan) }\end{array}$ & Lost & Public & Chabahil & Monastry \\
\hline 18 & Lamh Pokhari & Lost & Private & Chabahil & Lions Club \\
\hline 19 & $\begin{array}{l}\text { Pachali Bhairav } \\
\text { Pokhari (3 in No.) }\end{array}$ & Lost & Public & Teku & Abandoned \\
\hline 20 & Ghoilesang pokhari & Existing & Public & Boudha & Construction \\
\hline 21 & Khichha pokhari & Lost & Private & Sundhara & Abandoned \\
\hline 22 & Sorekhutte Pokhari & Lost & Public & Sorekhutte & Guthi \\
\hline 23 & Puwa pokhari & Lost & Private & Hadigaun & Residential \\
\hline 24 & Bhimsenstan Pokhari & Lost & Private & Hadigaun & Residential \\
\hline 25 & Raj Rajeshwari & Existing & Public & Pashupati & Abandoned \\
\hline
\end{tabular}

Source: Field survey 


\section{Deterioration of ponds and related stresses}

Many ponds couldn't be well preserved during Panchayat and early multi-party system. The physical stresses that are directly associated with the physical alternation of ponds either downsizing or removal of the vital water bodies over the period of time are water movement blockage, overuse of groundwater, dumping of waste and flow of domestic effluents, sediments' flow and improper management of religious waste in the water bodies (Mortimer, 1942). Most of the ponds in Kathmandu vanished due to the blockage of the water movement channel i.e. Raj Kulos. Most of the participants in the FGD stated that the construction activities like erection of foundation of large buildings, construction of drainage and pipe lines crossing the path of old channels feeding ponds, construction of roads, construction of shallow wells and also due to haphazard extraction of ground water through tube wells and hand pumps are the reasons which disturbed the movement of water movement. Puwa Pokhari in Hadigaun dried due to the excessive use of ground water which led the well in the pond to dry out resulting in the disappearance of the pond. Residents of Naxal dump their waste in Narayan Chour which is just 50 metres away from Nag Pokhari. Sediments not only decrease the size of the pond, also contributes to the biological activity leading to the disappearance of ponds. Lamh Pokhari which is also known as Jumbu kunda which is used to act as a buffer to protect from flooding which retained sediments which later vanished due to excessive sediment replaced water. Rani pokhari has been affected by the deposition of fine particles including organic matter. During the process of rain harvesting system from the roof of Tri-chandra College and Durbar High school, the soil particles are also transported to the pond. The religious offerings in the ponds aren't well managed either.

The societal stresses that led to destruction or obstruction in management of ponds are land encroachment and transfer of ownership, change of profession and habits like fetching water for household purposes, lack of organizational body and poor legislation and ineffective execution of rules and absence of deities in the pond. "Tragedy of Commons" and the principle of non exclusion seem to perfectly apply in terms of ponds and surrounding lands. People know that they are responsible for the degradation of the system but they think $\mathrm{KMC}$ and government are responsible to intervene and take necessary steps to restore the ponds. But, government organizations are seen to be reluctant to work to solve the issue is liable custodian according to Local Governance Act 1999 the liable custodian to conserve the national heritage is $\mathrm{KMC}$ and DDC. 


\section{Pond water quality concern}

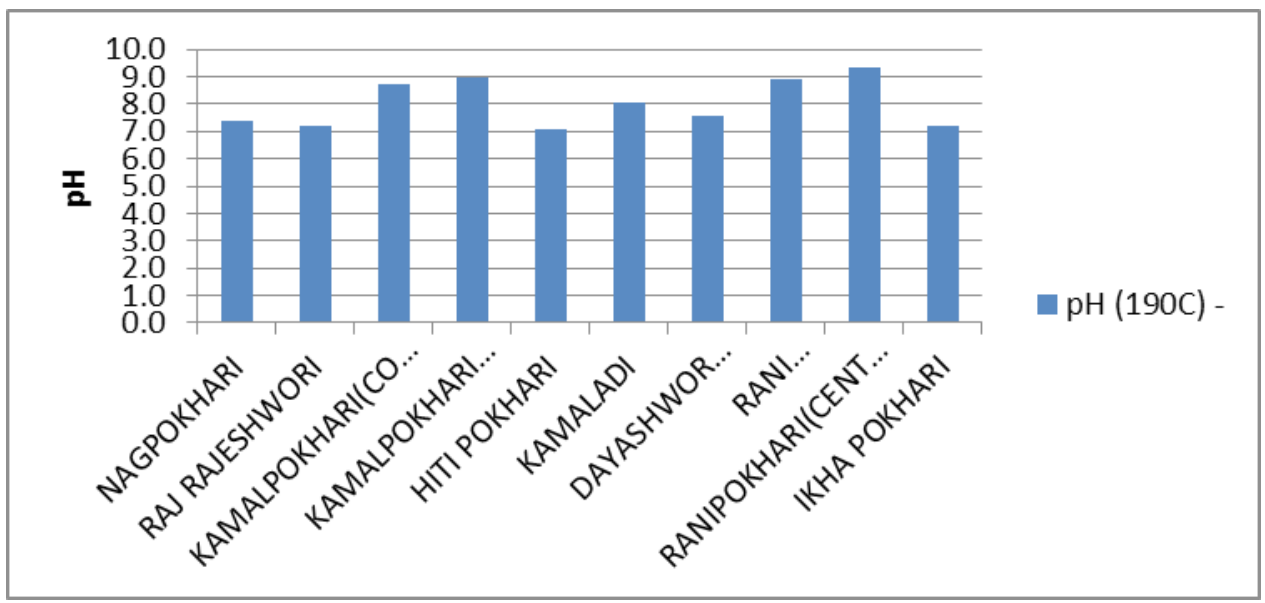

Figure 1 Variations in $\mathrm{pH}$ of pond water at different sampling sites

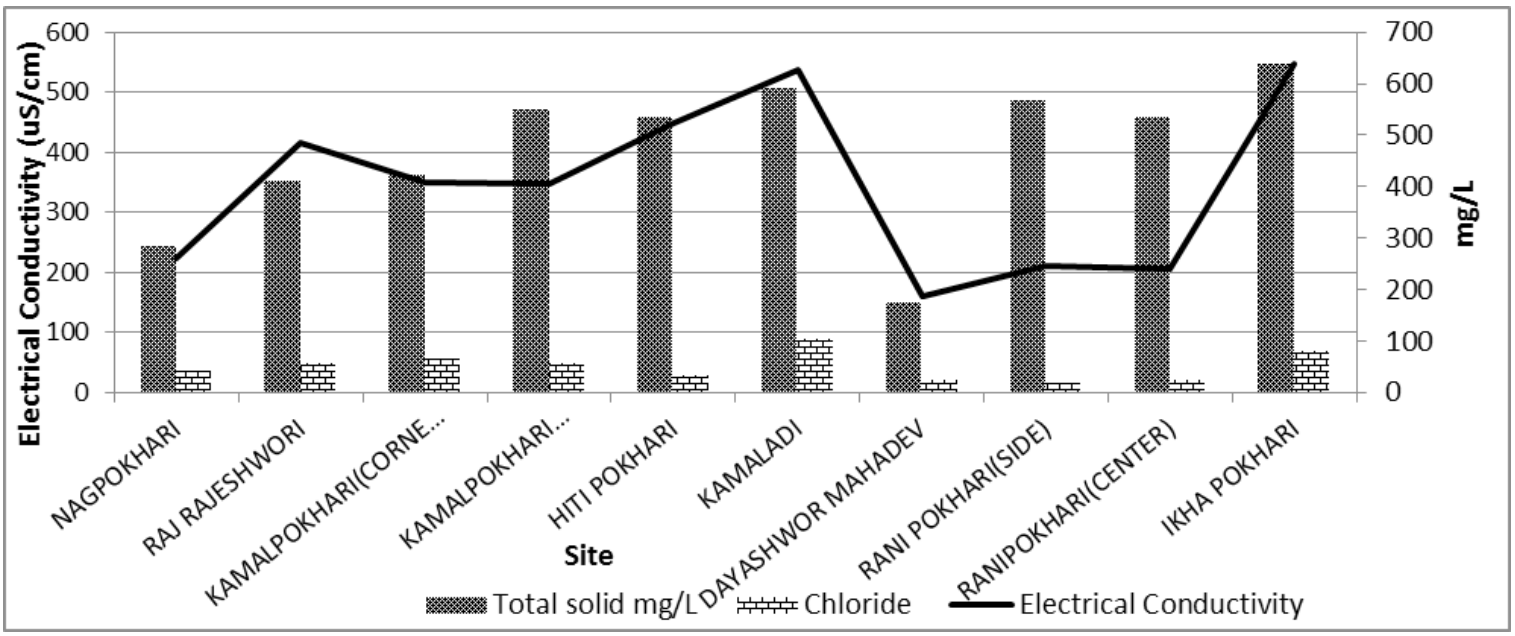

Figure 2 Comparative studies of EC, TS and $\mathrm{Cl}^{-}$of pond water at different sampling sites 


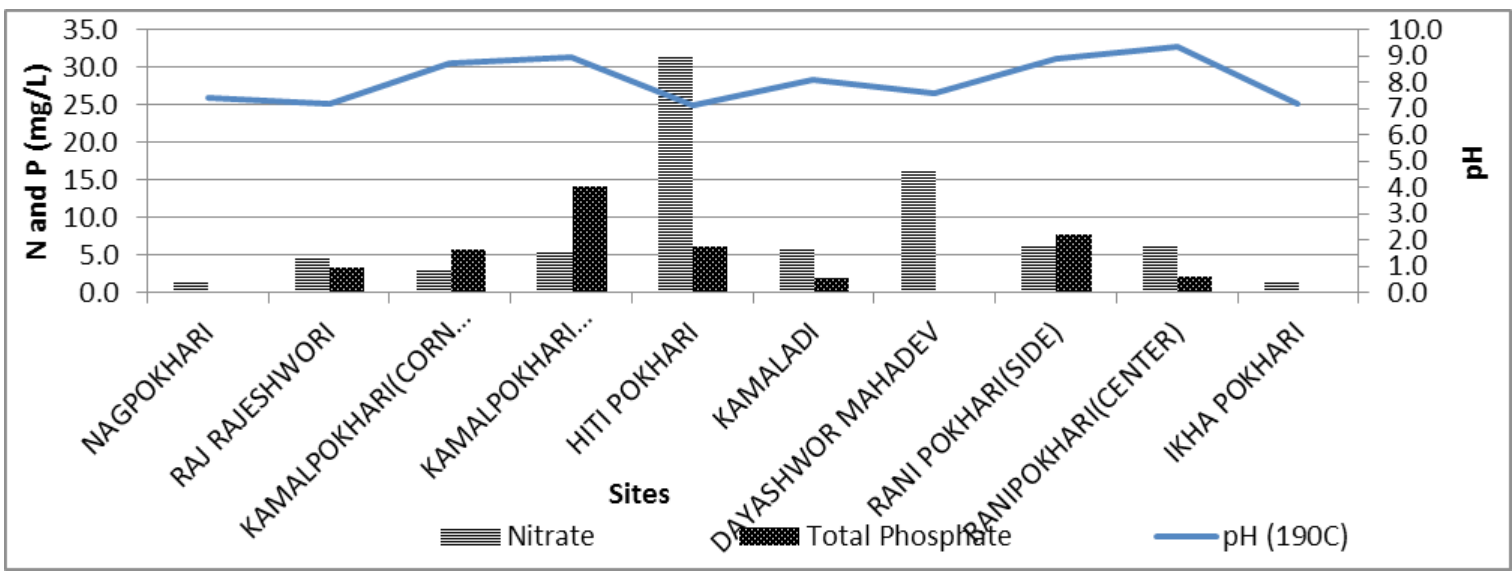

Figure 3 Comparative studies of nitrate and phosphate of pond water at different sampling sites

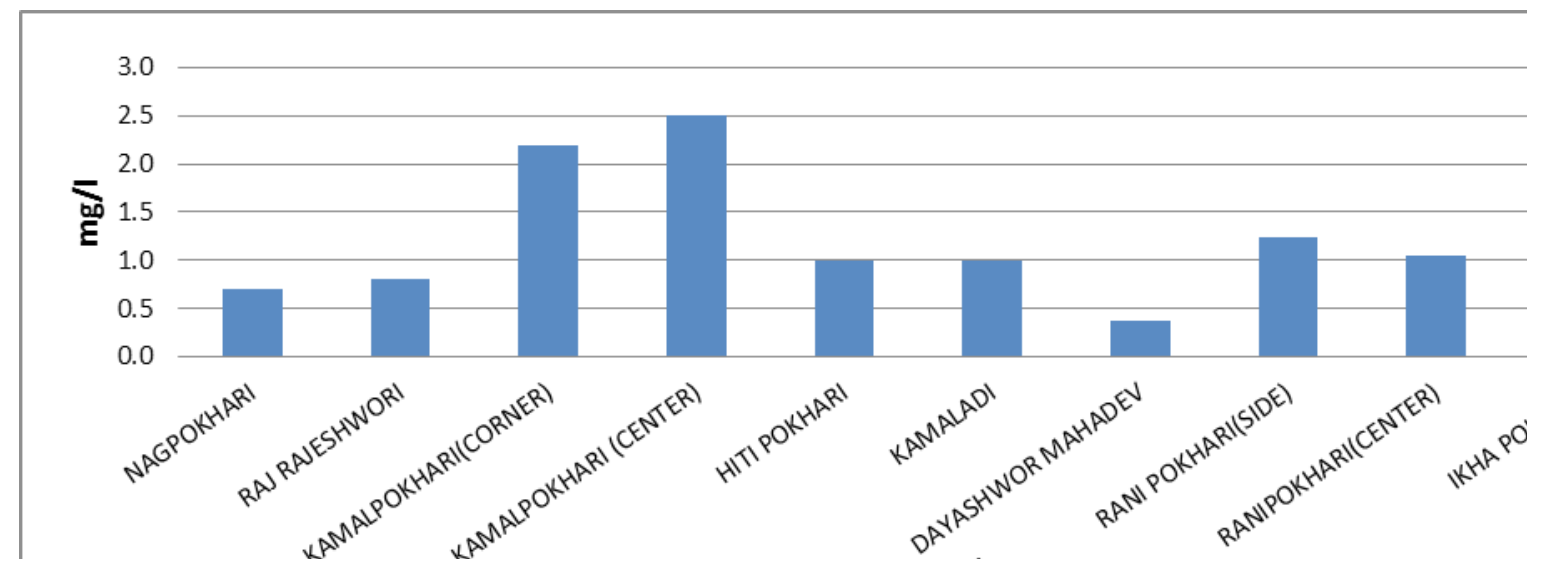

Figure 4 Variations in ammonia of pond water at different sampling sites. 


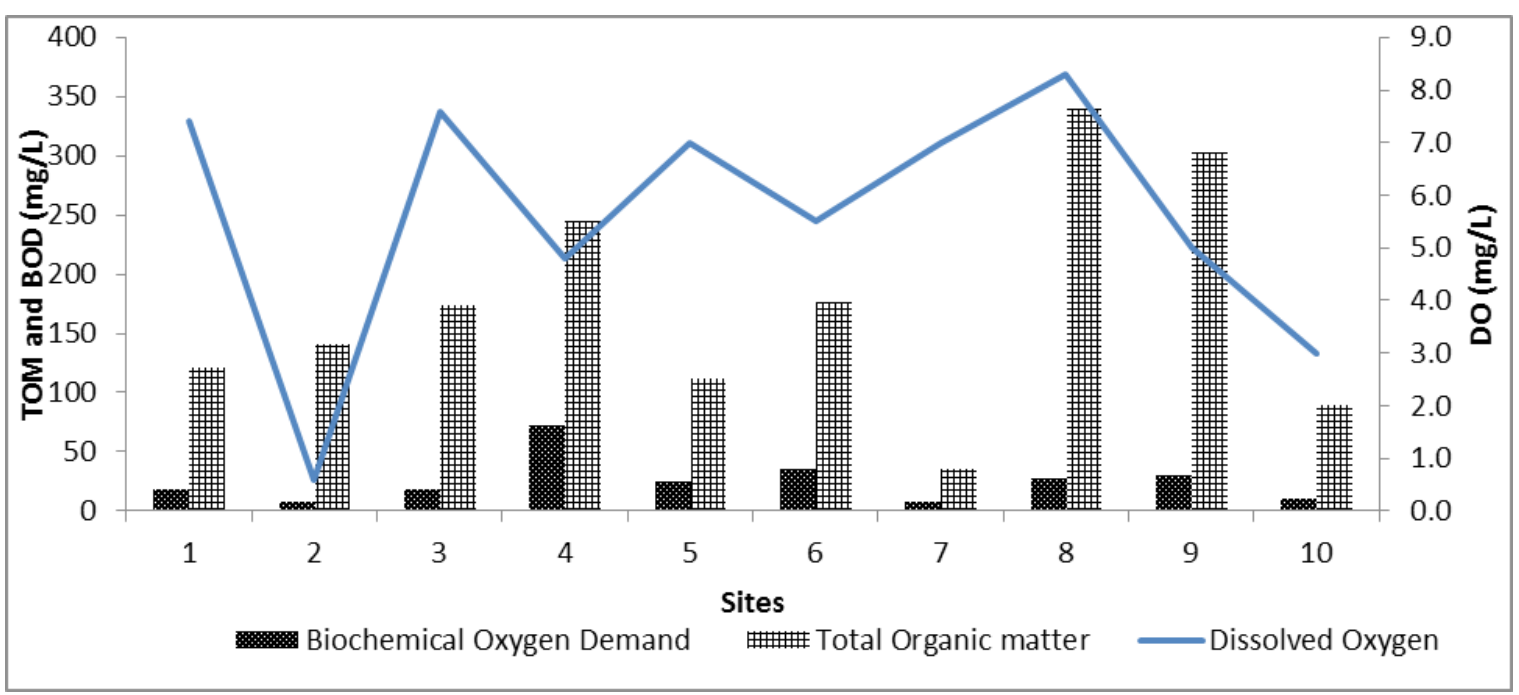

Figure 5 Comparative studies of DO, BOD and TOM of pond water at different sampling sites

Table 4: Variations in chlorophyll of pond water at different sampling sites

\begin{tabular}{|l|l|}
\hline Name of the Ponds & Chlorophyll $\left(\mathrm{mg} / \mathrm{m}^{3}\right)$ \\
\hline Nag Pokhari & 188 \\
\hline Raj Rajeshwori & 184 \\
\hline Kamal Pokhari (Corner) & 233 \\
\hline Kamal Pokhari (Center) & 1363 \\
\hline Hiti Pokhari & 118 \\
\hline Kamaladi & 208 \\
\hline Dayashwor Mahadev & 3 \\
\hline Rani Pokhari (Corner) & 727 \\
\hline Rani Pokhari (Center) & 390 \\
\hline Ikha Pokhari & 8 \\
\hline
\end{tabular}


Table 5: Variations in E. coli of pond water at different sampling sites.

\begin{tabular}{|l|l|}
\hline Name of the Ponds & E. coli count (CFU/100ml) \\
\hline Nag Pokhari & 26 \\
\hline Raj Rajeshwori & TNTC \\
\hline Kamal Pokhari (Corner) & TNTC \\
\hline Kamal Pokhari (Center) & TNTC \\
\hline Hiti Pokhari & TNTC \\
\hline Kamaladi & 480 \\
\hline Dayashwor Mahadev & 100 \\
\hline Rani Pokhari (Corner) & 420 \\
\hline Rani Pokhari (Center) & TNTC \\
\hline Ikha Pokhari & 16 \\
\hline
\end{tabular}

The data values of different parameters obtained fell below $10 \%$ in terms of Standard Deviation and are listed in the figures and tables as mean values. The value measurements did not alter significantly because during winter season, as there was so rainfall, water was supplied in the ponds so that it didn't get dried off.

Table 6: Physical status of the existing ponds in KMC in 1982

\begin{tabular}{|l|l|l|l|l|l|l|l|}
\hline $\begin{array}{l}\text { S. } \\
\text { No }\end{array}$ & Name of pond & Location & $\begin{array}{l}\text { Length } \\
(\mathrm{ft})\end{array}$ & $\begin{array}{l}\text { Breadth } \\
(\mathrm{ft})\end{array}$ & $\begin{array}{l}\text { Depth } \\
(\mathrm{ft})\end{array}$ & $\begin{array}{l}\text { Construction } \\
\text { date }\end{array}$ & Status \\
\hline 1 & Kamaladi Pokhari & $\begin{array}{l}\text { Kamaladi, } \\
\text { Ganeshstan }\end{array}$ & 79.10 & 39.7 & 4 & $18^{\text {th }}$ century & Protected \\
\hline 2 & Ikha Pokhari & Nyokha & 210 & 92 & 20 & $16^{\text {th }}$ century & Neglected \\
\hline 3 & Nag Pokhari & Bagdurbar & 72 & - & - & $19^{\text {th }}$ century & Neglected \\
\hline 4 & N/A & Haribhawan & 180 & 150 & - & $17^{\text {th }}$ century & Neglected \\
\hline 5 & Sorekhutte Pokhari & Sorekhutte & 100 & 50 & - & $\begin{array}{l}1864 \text { Kartik) BS } \\
(\text { Bhote Pande) }\end{array}$ & Neglected \\
\hline 6 & $\begin{array}{l}\text { Pachali Bhairav } \\
\text { Pokhari }\end{array}$ & $\begin{array}{l}\text { Pachali } \\
\text { Bhairav }\end{array}$ & 200 & 25 & - & $20^{\text {th }}$ century & Neglected \\
\hline 7 & $\begin{array}{l}\text { N/A } \\
\text { Teku, Rope } \\
\text { way }\end{array}$ & 180 & 100 & - & $20^{\text {th } \text { century }}$ & Neglected \\
\hline 8 & $\begin{array}{l}\text { Raj Rajeshwori } \\
\text { Pokhari }\end{array}$ & $\begin{array}{l}\text { Raj } \\
\text { Rajeshwori } \\
\text { (Pashupati) }\end{array}$ & 50 & 20 & 6 & $18^{\text {th } \text { century }}$ & Protected \\
\hline 9 & $\begin{array}{l}\text { Nag Pokhari } \\
\text { (Bhagwanstan) }\end{array}$ & Chabahil & 80 & 50 & - & $\begin{array}{l}18^{\text {th }} \text { century } \\
(\text { Charumati })\end{array}$ & Neglected \\
\hline
\end{tabular}




\begin{tabular}{|l|l|l|l|l|l|l|l|}
\hline 10 & Ghoilesang pokhari & Boudha & 200 & 50 & - & $19^{\text {th }}$ century & Protected \\
\hline 11 & Puwa Pokhari & Hadigaun & 50 & 40 & - & $18^{\text {th }}$ century & Neglected \\
\hline 12 & Gahana Pokhari & Hadigaun & 75 & 40 & & $16^{\text {th }}$ century & Protected \\
\hline 13 & $\begin{array}{l}\text { Dayeshwor } \\
\text { Mahadev Pokhari }\end{array}$ & Lazimpath & 7 & 4 & 12 & N/A & Protected \\
\hline 14 & Nag Pokhari & Naxal & 125 & 65 & 7 & $\begin{array}{l}17^{\text {th }} \text { century } \\
\text { Queen Subarna } \\
\text { Prabha) }\end{array}$ & Protected \\
\hline 15 & Kamal Pokhari & $\begin{array}{l}\text { Kamal } \\
\text { Pokhari }\end{array}$ & 350 & 175 & 35 & $19^{\text {th }}$ century & Neglected \\
\hline 16 & Rani Pokhari & Ratna Park & 590 & 460 & 3.7 & $\begin{array}{l}17^{\text {th }} \text { century } \\
\text { (Pratap Malla) }\end{array}$ & Protected \\
\hline
\end{tabular}

Source: KVTDP, 1982

Table 7 Physical Status of the existing ponds in KMC in 2010

\begin{tabular}{|l|l|l|l|l|l|l|l|}
\hline $\begin{array}{l}\text { S. } \\
\text { No }\end{array}$ & Name of pond & Location & $\begin{array}{l}\text { length } \\
(\mathrm{ft})\end{array}$ & $\begin{array}{l}\text { Breadth } \\
(\mathrm{ft})\end{array}$ & $\begin{array}{l}\text { Depth } \\
(\mathrm{ft})\end{array}$ & $\begin{array}{l}\text { Construction } \\
\text { date }\end{array}$ & Status \\
\hline 1 & Kamaladi Pokhari & $\begin{array}{l}\text { Kamaladi, } \\
\text { Ganeshstan }\end{array}$ & 79.10 & 39.7 & 3 & $18^{\text {th }}$ century & Protected \\
\hline 2 & Ikha Pokhari & Nyokha & 210 & 92 & 12 & $16^{\text {th }}$ century & Neglected \\
\hline 3 & $\begin{array}{l}\text { Raj Rajeshwori } \\
\text { Pokhari }\end{array}$ & $\begin{array}{l}\text { Raj } \\
\text { Rajeshwori } \\
\text { (Pashupati) }\end{array}$ & 50 & 20 & 4 & $18^{\text {th }}$ century & Neglected \\
\hline 4 & Gahana Pokhari & Hadigaun & 75 & 40 & 4.5 & $16^{\text {th }}$ century & Dried up \\
\hline 5 & $\begin{array}{l}\text { Dayeshwor } \\
\text { Mahadev Pokhari }\end{array}$ & Lazimpath & 59 & 23 & 12 & N/A & conserved \\
\hline 6 & $\begin{array}{l}\text { Nag Pokhari } \\
\text { Naxal }\end{array}$ & 125 & 65 & 5.5 & $\begin{array}{l}17^{\text {th }} \text { century } \\
(\text { Queen } \\
\text { Subarna } \\
\text { Prabha) }\end{array}$ & Protected \\
\hline 7 & $\begin{array}{l}\text { Kamal Pokhari } \\
\text { Kamal }\end{array}$ & 350 & 175 & 15 & $19^{\text {th }}$ century & Protected \\
\hline 8 & $\begin{array}{l}\text { Rani Pokhari } \\
\text { Pokhari }\end{array}$ & Ratna Park & 590 & 460 & 3.5 & $\begin{array}{l}17^{\text {th }} \text { century } \\
\text { (Pratap } \\
\text { Malla) }\end{array}$ & Conserved \\
\hline 9 & $\begin{array}{l}\text { Hiti Pokhari }(2 \\
\text { ponds })\end{array}$ & $\begin{array}{l}\text { Narayanhiti } \\
\text { path }\end{array}$ & $91 / 43$ & $69 / 36$ & N/A & N/A & Protected \\
\hline
\end{tabular}

Source: Field Survey 


\section{Conclusion and Recommendations}

The unplanned urbanization led to the vulnerability of the ponds and water spouts. The rampant construction of buildings and roads caused physical alteration of the ponds by downsizing or complete removal of ponds. The excess extraction of ground water brought fluctuations in the ground water level and the movement of water into ponds and local aquifers were largely reduced. Other impacts of construction works caused sedimentation lowering the depth of the ponds. The area of Ikha Pokhari and Kamal Pokhari has reduced by two third and by a quarter of its original area respectively. The presence of higher concentration of ions and salts indicates the water is more alkaline and increasing concentration of solids made water aesthetically poor. The concentration of phosphate and nitrate are comparatively high than the previous study carried by the ENPHO and TUTA, which is a clear indication of presence of domestic waste, human and animal excreta and religious waste. Except Dayashwor Mahadev Pokhari all other ponds are in the state of eutrophication since the concentration of nutrients and organic matters are high and $\mathrm{N}$ : $P$ ratio is smaller. Most of the ponds have DO value less than $5 \mathrm{mg} / 1$ which is less than what water can dissolve oxygen at standard temperature. The ponds have high amount of chlorophyll which indicate the unacceptable ecological status. All the ponds contain $E$. coli the primary cause of water borne disease. Social and legal structures are not keeping the same pace as urbanization. Only Rani Pokhari, Nag Pokhari and Kamal pokhari are given some attention for their conservation but other five ponds are not given any attention. Kamal Pokhari youth club looks after Kamal Pokhari, Naxal Yuwa Mandal looks after Nag Pokhari and KMC is directly involved in the conservation of Rani Pokhari but these intervention activities are not enough for the protection of ponds and pond area. If any defined interventions are not done from the government, community and development organization, there is a high chance of ponds to disappear from $\mathrm{KMC}$ in near future. Ponds which have vanished are gone and cannot be revived but the ponds which exist can be given enough attention and revived for recreational and emergency use.

Maintaining ponds in its original state not only preserve the environment but also conserve the cultural heritage. They are also very important to recharge the ground water. Ponds, network of canals and stone spouts have a close relationship and used to serve water for the population of Kathmandu both in quality and quantity before piped water system was introduced. Cautions were not taken in conserving the time proven technology and with the weak management of modern piped system people are looking back to old systems. These challenges require sustainable management of water resources which include local people in the decision making process. The water quality is found to be inappropriate for domestic 
purposes nor suitable for fishery and swimming. Human activities which restrict the pond environment should be limited in the pond. The disposal of sewages, polluted rainwater, garbage, etc. should be controlled. Water quality assessment should be monitored at regular interval. Ponds are not only the site for aesthetic beauty but a very important entity of ecosystem and have diversified use. The Metropolitan City should organize awareness program for the local clubs, schools, and local leaders for the conservation of ponds and stone spouts. Effective rules and regulations should be formulated including the key stakeholders and local people for the management of ponds. It is a prime responsibility of the government to address the issue of land ownership and construction of house and infrastructure that damage or restricts the natural water flow. Proper mechanism should be developed for the regular aeration of water in the ponds such as fountains so that the ponds has more dissolved oxygen eliminating faulty smell and control fish death.

\section{Conflict of Interest:}

The authors confirm that the data supporting the findings of this study are available within the paper itself and is not published before.

\section{References}

Amatya, S., 2003. Water and Culture. Kathmandu, Nepal: Jalsrot Vikas Sanstha (JVS).

Antoni, C.S. and G.Verardi, 1985. Excavation in the Kathmandu Valley. In ancient Nepal

No. 8, Department of Archaeology, HMG of Nepal

CBS. 2001. Statistical Year Book of Nepal 2001. Kathmandu, Nepal: Central Bureau of Statistics (CBS).

CBS. 2002. National Population Census. Kathmandu, Nepal: National Planning Commission Secretariat.

CBS. 2011. Population Monograph of Nepal: Vol.-2. Kathmandu, Nepal: Central Bureau of Statistics (CBS).

DHM 2015

Dixit, A., and Upadhaya, M. 2005. Augmenting Ground Water in Kathmandu Valley: Challenges and Possibilities. Kathmandu, Nepal: NWCF.

Graney, J. R., and Eriksen, T. M., 2004. Metals in pond sediments as archives of anthropogenic activities. A study in response to health concerns,-Appl. Geochem, 19, pp.1177-1188.

Haack, B., 2009. A history and analysis of mapping urban expansion in the Kathmandu valley, Nepal. The Cartographic Journal, 46(3), pp.233-241. 
Joshi, P. R., 1992. Historical Hiti and Pokharis: Traditional Solutions to Water Scarcity in Patan. Patan Conservation and Development Programme, UDLE/GTZ.

Maharjan, K. 2012. Seasonal changes in Physico-Chemical parameters of Lentic Environment- Ranipokhari, Kathmandu, Academic View, and Research oriented Yearly Journal of T.U. Teachers'Association, Tri-Chandra campus Unit Committee, Vol.3

Mortimer C. H., 1942. The exchange of dissolved substances between mud and water in lakes. J. Ecol., 30, pp.147-201.

Pant N. R. 1988, Lichchhavi Samvatko Nirnaya (In Nepali). Kathmandu: Royal Nepal Academy 1988

Pant N. R. 2009, Kathmandu Valley Profile. Kathmandu: Briefing Paper, 2009

Pradhan, R., 2003. A History of Water Management in Nepal: Culture, Political Economy and Water Rights. -Law, History and Culture of Water in Nepal. FREEDEAL, pp. 17-62.

Pradhan, R., 1990. Dhunge Dhara: A case study of the three cities of Kathmandu Valley. Ancient Nepal: Journal of the Department of Archaeology, 116, pp.10-14.

Sharma, P. 1992: A note on recent trends in Nepal's urbanization. The Himalayan Review, xx-xxiii:pp. 1-10.

Sharma, P., 1989. Urbanization in Nepal. Honolulu, Hawaii: East-west Population Institute.

Shrestha, R. T., 2003. Religious and Secular Uses of Ponds in Nepal-Law, History and Culture of Water in Nepal. FREEDEAL., pp.77-92.

UN-HABITAT, 2008. Water Movement in Patan with Reference to Traditional Stone Spouts in Nepal. UN-Habitat Water for Asian Cities Programme Nepal, Kathmandu 